\section{THE NEOLIBERAL IDEOLOGY, ITS CONTRADICTIONS, THE CONSEQUENCES AND CHALLENGES FOR SOCIAL WORK}

The article shows the influence of neoliberalism on social work and tries to give answers following the International Federation of Social Work (IFSW) Code of Ethics (4.2.4 social justice - Challenging unjust policies and practices). Neoliberalism can be described as an economic-political project of capitalist elites which involves the following: economization of all areas of life, privatization, economic globalization and deregulation. The article will give a short historical overview of the development of neoliberalism, the myths and tenets of the new neoliberal ideology and the "manufacturing of consent" (Herman and Chomsky, 1994). Additionally, the article will describe the consequences for social policy and social work, which include the reduction of the welfare state and a development that can be outlined with the following key terms: economization of social work, work-fare instead of welfare. Finally the article will describe the reaction of social work on this development. Some necessary anti-strategies will also be discussed.

1 Professor Christian Stark, Ph.D., social worker,

e-mail: christian.stark@fh-linz.at 


\section{INTRODUCTION}

Since the fall of the Iron Curtain and against the background of a dominant neoliberal ideology, the market has increasingly become the organizational principle for governments and societies. In this context, even social work has been economized and subjected to the logic of market and profit. This is connected to strengthened methods and concepts of business management - the idea of running social work as a private business has made its entry into the field with promises of more effectiveness and efficiency and a more visible improvement of quality in social work. In the analysis of the economic processes within the social work profession since the 1990s, too little attention has been paid to the fact that the focus of efforts is not the wellbeing of the client or an improvement in the quality of the social work, but rather the preservation of resources. The economization of social work is a kind of Trojan horse. Professional social work has been made to follow objectives inimical to the profession: cost saving instead of providing help by promoting conditions of life conducive to the welfare of human beings. Strict housekeeping and costs - not a professional diagnosis - predominantly determine what is considered to be useful, efficient and feasible; as a rule, making successful savings is placed above success in providing help. In a hermeneutic and descriptive analysis this article highlights the influence of neoliberalism on social work and describes how social workers are reacting to this process.

\section{THE HISTORICAL DEVELOPMENT AND POLITICAL IMPLEMENTATION OF NEOLIBERALISM}

The term neoliberalism often serves as a political catchphrase with different meanings such as an ideological movement, the imperialist expansion of the U.S. or the general trend towards the economization of society. Neoliberalism means literally a new liberalism. The old economic liberalism emerged in the Anglo-Saxon countries towards the end of the $18^{\text {th }}$ century and beginning of the $19^{\text {th }}$ century. It acquired its theoretical foundation and made its breakthrough with Adam Smith and his book "An Inquiry into the Nature and Causes of the Wealth of Nations". Smith enhanced the abolition of government intervention in economic matters and free market as the best way for a nation's economy to develop. Smith's central thesis is that the engine of all economic activities is the self-interest of human beings. The principle of supply and demand and the so-called invisible hand of the market are the regulatory principles which lead to success and wealth (Smith, 1976). This is the reference frame for neoliberalism. In demarcation to this old liberalism

\section{0 articles}


neoliberal economists criticize the deficient institutional protection and framing of the free market by the state and transform market economy to a market society. The Great Depression of 1929 and the following world economic crises in the 1930s marked the end of the liberal era. Considering the crisis, the idea of self-regulation of the market was not to be upheld. In 1936, John Maynard Keynes in his »General Theory of Employment, Interest and Money « designed a theory that challenged liberalism as the best economic policy. Keynes stated that the deficits of capitalism were in the inability of the market to set up an effective production and distribution system which would ensure security for the entire population. In view of this inability, complementary intervention in the market by the state was necessary (Wilke, 2002: 30-126). Keynes' theory gave a new direction to economic policy over the next 30 years and became famous as Keynesianism. This fundamental defeat of the economic liberalism simultaneously marked the birth of neoliberalism as a counter-movement to Keynesianism. As a reaction to the growing Keynesianism, market-radical economists formed an international movement. The birth hour was an international conference in Paris 1938 organized by Walter Lippmann: the so-called »Walter Lippmann Colloquium«. It was the first international meeting of market-radical economists and gathered the most prominent of them, such as Friedrich A. von Hayek, Ludwig Mises, Wilhelm Röpke and Walter Eucken. It was there that the term neoliberalism was coined and neoliberalism, formally designed as an economic policy counter-concept to Keynesianism (Hennecke, 2000: 137-139; Harvey, 2007: 16-21).

After World War II, in 1948, the Mont-Pelerin-Society was founded under Hayek's direction to establish an international network of foundations, institutes, research centers, journals and public-relations-agencies - to support and spread neoliberal thinking. The Mont-Pelerin-Society became the most important network with currently 1000 members and 100 networked think tanks. Its scientific breakthrough succeeded with a series of awards of the Nobel Prize for Economic Sciences for neoliberal economists (e.g. Friedrich A. v. Hayek 1974 and M. Friedman 1976). With the writings of Hayek and Friedman and the lobbying activities of the think tanks, the neoliberal doctrine became more and more dominant at universities, occupied the Economic Sciences and influenced more and more experts. It permeated the structures of institutes, corporations, international organizations and governments and thereby received definitive power. Its most crucial political establishment succeeded in the late 1970s and early 1980s, the decisive factor being the economic crisis of 1973, which signified the end of economic growth and gave neoliberal thinkers the possibility to accuse state economic policy for economic failure. The first experimental field for neoliberal economic policy was Chile after the CIA-supported coup against the popularly elected Allende regime in 1973. Since 
1975 the representatives of the Chicago School under the direction of Milton Friedman have subjected Chile to a neoliberal restructuring, starting with the support of the military regime of Pinochet. Under Prime Minister Margret Thatcher in 1979 and the presidency of Ronald Reagan in 1980, the political implementation moved from the periphery to the center. People started to speak about Reaganomics and Thatcherism. With the dismantling of the Iron Curtain and the end of communism in the Soviet Union in 1989, neoliberalism became the predominant economic doctrine - so much so that Margret Thatcher stated, »There is no alternative - this was later called the TINA-Syndrome. The main measures of the governments were privatization of public institutions, tax incentives for corporations, cutbacks in social benefits and the busting of trade unions (Harvey, 2007: 25; 32-42). Another important step was the end of the Bretton Woods system: the end of reined in currency exchange rates with the US dollar as a base and the tie of the currency to the gold standard. This meant the sweeping deregulation and globalization of the finance market in the 1990s and led to the so-called Casino-capitalism.

\section{THEORETICAL PRINCIPLES OF THE NEOLIBERAL DOCTRINE}

Neoliberalism is an economic policy concept. It is an ensemble of economic theories, state policies and concern strategies. There is no cohesive neoliberal theory. There are different academic streams such as the Austrian School with its main representatives Ludwig von Mises and Friedrich A. Hayek, the monetarism of the Chicago School around Milton Friedman, the rational choice approach of Gary Becker or the public choice approach of James Buchanan (Butterwegge, Lösch and Ptak, 2008: 24-26).

All of them share the aspects that are going to be presented.

\section{Universal claim: Market society}

The claim of neoliberalism is universal. The market serves as a universal model of organization and all areas of life are subjected to the logic of the market: the market economy turns any given society into a market society. There must be nothing which is not regulated by market logic. Altvater (1981: 15) refers to the imperialism of the economy. The ultimate goal of neoliberalism is a human society in which every action between human beings is a market transaction, conducted in competition with other human beings. Therefore, the market metaphor is applied to regions, nations, cities and individuals. They are seen as business firms positioning

\section{2 articles}


themselves as possible investments in a national and global marketplace. From this point-of-view, the Deutschland GmbH competes with Great Britain Ltd, USA Inc., etc. On a personal level, the general neoliberal vision is that each human being is an entrepreneur managing their own life - I, Inc.

\section{The perfect market and the spontaneous order}

One basic assumption of neoliberalism thinking is the construct of entire and perfect competition, where there are suppliers and demanders, who have optimal access to information and enjoy perfect market transparency to produce balanced and efficient market results. According to Hayek (1971), the market is not created by man, because man is not intelligent enough. Market is a result of selection by evolution. The free market generates a form of Darwinian selection: the survival of the competitive. There is no social knowledge, only individual knowledge and individual knowledge is limited. The market merges the imperfect knowledge of the individual with the competition process and produces the so-called spontaneous order. This order is not predictable. State interventions in the market are pretentions of knowledge, they dissolve the spontaneous order and lead to a coercive system. Man's only possibility is to adjust to the spontaneous order (Hayek, 1971: 31-33; Kreuzer, 1983: 21).

\section{Neoliberalism and social policy}

The welfare state in all its manifestations and all varieties of socialism and collectivism are seen as the mother of all evil. The social is an ideological figure and not a definable ideal of thought; it only serves to undermine the rules of the market to which we owe our wealth. Demands for social justice limit the right to unlimited private property. Altruism and solidarity are described as low collective morals and tribal instincts; and, according to Darwin's social evolution theory, are even a rebellion against higher standards of civilisation and to be seen as amoral (Hayek, 1979: 16; Blankenburg, 1997: 79). Hayek cannot understand the term social at all: »/ have spent more than 10 years searching intensively for the meaning of the term social justice. I have failed in this or, rather, I have come to the conclusion that the term has no meaning for a society of free people (...) Social does not refer to a definable ideal, but today only serves to take away the meaning of the regulations of free society, to which we all have to be grateful for our affluence. Even if some people will be horrified to hear it, I have to say that I cannot think socially, because I do not understand what that means« (Hayek, 1979, cited in Kurz, 2001: 752). 
Based on the slogan "everybody is the architect of their own fortune«, poverty is regarded as a crisis of one's own making and a just penalty for non-performance. The necessity of economic power, education and material means to enjoy freedom is dismissed completely. The state and enterprises have no social responsibility mass unemployment and starvation are accepted as side effects of a free market. The only social responsibility of entrepreneurs is the responsibility for the profit of the shareholders: »There are few developments which can undermine the fundaments of our society as basically as the opinion that entrepreneurs have any other social responsibility than to gain as much profit for their share-holders as possible (Friedman, 1976: 176). Green puts it even more bluntly: »Let fall those who must fall. Such is the jungle of economic life. A jungle of savage beasts, where he who can kill the one next to him, kills him (Green, 1995: 155).

Neoliberal thinkers might have benefitted from studying Adam Smith who mentioned that man's selfish passions must be regulated by feelings of sympathy for their fellow beings guided by rules of ethics and benevolence (Smith, 1966, cited in Rosen, 1991: 306). So you may define neoliberalism with Negt (1997: S.38) as »...a capitalism which is liberated from all democratic and social inhibitions and scruples". The main resultant claims from this neoliberal theory are free trade, deregulation and privatization. Free trade means freedom of movement for global transfer of goods, services, capital and investments. This implies deregulation: the reduction of rules and laws which impede free trade, such as social and environmental standards in order to remain competitive on the world market. Rules to protect the employee and the environment are regarded as obstacles for investments and restrictions of freedom for entrepreneurs. But deregulation doesn't mean complete renouncement of state interventions. The state has to serve as an instrument of private economic interests, to guarantees the necessary conditions of a free market focus on the support of economic competitiveness and profitable capital utilization. Neoliberalists also demand the sweeping privatization of state-owned enterprises and public institutions. This includes key industries, railroads, toll highways, electricity, schools, water, the health, the social and the justice system. They argue lacking efficiency and better performance by private investors due to competition pressure. The state should remain responsible only for basic order and security in the sense of the classic night watchman state.

\section{4 articles}




\section{CONTRADICTIONS AND CRITIQUE OF NEOLIBERALISM}

\section{Freedom and free market}

The term freedom is used arbitrarily in accordance with a certain doctrine and connected interests: it is reduced to free enterprise and freedom of private property. Polanyi (1978: 339) calls this bad freedom: the freedom for entrepreneurs to exploit workers, to make exorbitant profit with no proper performance for society and to use technological progress only for making profit and not for the wellbeing of society. You might also call it the freedom of wolves to chase "free« chickens cooped up in a henhouse?

The free market is a political and social regime. It is neither spontaneous nor endemic to humans. If no-one ever enforced it, there would be no free market. The modern free market came into existence primarily because liberalism demanded it and this demand was enforced by the state. Hence, the market is a structure deliberately imposed to implement the goals of a neoliberal ideology. Historical and current practice seem to suggest that free market is only a highly moralizing rhetorical figure. »The free market as it existed in mid-Victorian England came about not because the state withdrew from the economy, but rather because state power was used to privatize land that had been under various forms of common ownership, or not owned at all. The laissez-faire economy that existed for a few decades in 19th-century England was made possible by the Enclosure Acts« (Gray, 1999: 288).

The EU-domestic-market is also a result of political decisions and not of Darwinian selection. There appears to be an inconsistency in neoliberal acting. On the one hand, neoliberal economists and their powers such as the International Monetary Fund claim free trade and force countries of the global south to open their borders for Western goods; on the other hand, farmers in the EU and the US get more than 300 billion dollars in subsidies. Therefore, the farmers in the countries of the global south are no longer competitive and are expelled from their home market. Nicholas Stern, a former economist of the World Bank commented on this: »/t is hypocritical to force the poor countries to open their markets and at the same time to protect our own markets with subsidies and protective duties« (Stern, 2002). Ordinary power policy is hiding behind the rhetoric of freedom. Concerning the US free trade policy, Chomsky contends that (1997:8) »...nobody believes in free trade... and if free trade does not give the desired results you abandon it«. Hayek's so-called spontaneous order totalizes market relations: the market economy is no longer seen as one possible principle of economic acting, but as the only one and it is identified with society. The spontaneous order creates structural violence and represents a universal euphemism of unshakable practical constraint, exercised by impersonal 
invisible powers. The liberation from feudalist society has led human beings into the neoliberal straightjacket of spontaneous order, which subjugates everybody. Society is not a frame for the market, not an independent category. The examples of a grave-digger, a policeman or a social worker show that a market philosophy cannot be extended to all areas of society - how can they fulfill their social function in accordance with the demands of the market?

Neoliberals neglect, silence and hide that the market reality is influenced by many other factors which contradict the neoliberal theory of free market: e.g. advertising and the creation of artificial needs or the so-called planned obsolescence. In addition, political scandals and anti-trust violations show that below the sphere of the neoliberal market logic there is a web of relationships, a network of personal, social and familial obligations, which counteracts neoliberal theory. Competition is a characteristic of the free market, but its supporters do not tolerate any competitor for the free market itself. The neoliberal thesis of perfect information and equal initial conditions represents a naive utopia and a deliberate disguise of procedures which inevitably lead to monopolies and the concentration of wealth.

\section{The non-coercion principle}

On the one hand, neoliberal thinkers demand freedom from state interventions and on the other hand, they demand that state should guarantee the functioning of the free market. As an instrument of repression and support of the market economy, the state is rearmed instead of disarmed. History shows how Neoliberalism has been imposed by governments, powerful organizations and military forces as demonstrated by Pinochet in Chile and by Reagan and Thatcher. The values of neoliberalism have to be enforced, just like those of any other political ideology. As a result, there is a selective benefit from the non-coercion principle: most explicitly, market forces are not defined as coercion. On the other hand, any attempt to restrict market forces would be defined as coercion. Public expenditures for social services should be cut, on the other hand there is no opposition to government subsidies and tax benefits for business.

\section{Privatization}

Although neoliberal thinkers demand privatization, current practice appears to follow the opposite trend: during the most recent financial crises, banks were saved by the state and, ultimately, by the taxpayers. As Chomsky (2010: 219) says: "Capitalism means privatization of profit and socialization of cost and risks«. The neo-

\section{6 articles}


liberal concept of privatization confirms the original meaning of the Latin word privare which means rob. It is eliminating the concept of the public good. What belongs to everybody (public goods) suddenly becomes the property of a few. Reality is obvious testimony to the disaster of privatization, e.g. the privatization of the British rail tracks or the privatization of water in Bolivia. The results were more costs and worse service (Reimon and Felber, 2003). Although usually done in the name of greater efficiency, privatization has mainly had the effect of concentrating wealth even more in a small number of hands and making the public pay even more for its needs. Butterwegge (1999: 435) summarizes: »No economic necessity is hiding behind the concept of privatization but a political calculation of mighty interest groups«.

\section{Conclusion}

Neoliberal theory is characterized by inconsistency in its internal logic. Many phrases are just simple rhetoric and propaganda tricks. Neoliberals do not really attempt a serious discourse on pending problems. Neoliberal discourse is more or less an internal conversation which exhausts itself by repeating its own paroles and simply ignoring dissent (Nawroth, 1961: 18; Butterwegge, Lösch and Ptak, 2008 : 26). Neoliberal thinking is a belief system - based on the belief in market and its forces. The market is personalized, acting like a God with an invisible hand, but only producing goods for the rich. Maaser calls it the metaphysics of the market (Maaser, 2003: 26). Krätke (1999: 100) calls neoliberalism a world religion. Bourdieu (1998: 109) describes neoliberalism as a utopia of unlimited exploitation and raises the question of whether we are too easily taken in by the neoliberal's utopia, a utopia which has managed, in the slipstream of economic theory, to conduct itself as a scientific description of reality. Therefore, neoliberal theory is ideology in the proper sense, the worldview of the ruling class. It is essentially faith masquerading as knowledge.

\section{THE POLICY AND PROCESS OF NEOLIBERAL TRANSFORMATION}

The establishment of neoliberal thinking succeeded by what Chomsky called fabrication of consent (Chomsky and Achbar, 1996). To modify Marx' phrase "the moral of the rulers is the ruling moral « you can say the ruling ideas have to become the ideas of the rulers. Or in the way George Orwell describes it in 1984: »And when all others believed the lies which were spread by the party - when all records told the same tale - then the lie went down in history and became the truth (Orwell, 2008). 
Hayek strengthened the Long March through the institutions such as universities, business schools, media, churches and a long dated education of public opinion. He distinguished between original thinkers - the neoliberal elite, who design the program - and the second-hand dealers of ideas, who influence policies and public opinion (Hayek, 1954: 17). Neoliberal theory has to be translated into propagandistic, manageable and psychologically operant discourses to change people's consciousness (Jäger, 1994: 26). Neoliberal special discourse as a discourse of elite neoliberal thinking interferes with the daily discourse and intrudes as the only possible and rationally legitimate discourse, thereby transforming societal speech forms (Jäger, 1994: 30). Gerlach (2000) speaks about a process of poisoning people's thoughts. This is a creeping process which succeeds by habituation. Poisonous tales about social abuses, debates about saving money and resources were generalized and have permeated public consciousness. Talk of debates about savings is being misused to the shattering of the social state.

The construction and perpetuation of stereotypes such as abusers of the welfare state, social scroungers, social hammock, is creating strong prejudices in people's thinking. These ideas are purposely marginalizing the unemployed, the homeless, asylum-seekers, etc. and diverting suspicion from the real culprits. The victims become offenders: the unemployed, the homeless and welfare recipients are responsible for empty public purses, not the tax-evading multinational concerns and multi-billionaires. Politicians and managers speak about having to tighten our belts, about living beyond our means, while they themselves have filled their pockets (Gerlach, 2000). Labor law and social rights (dismissal protection, unemployment benefit, continued pay in case of sickness) are criticized as preservation of ownership, but this is not an issue when it comes to the private property of multi-billionaires (Martin and Schumann, 1996: 213). These negative events bolstered by euphemistic forms of speech are represented as desirable: everything will be made flexible and rationalized. Words such as rationalization, flexibility, employability reduction of obstacles for investment, downsizing firms are minimizing language. Flexibility, for instance, means that workers are always available for work and can be called up at any time on an hourly or daily basis. The concept of reform, which was associated with the former plan aimed at achieving more social justice, better educational opportunities and a social safety net, is now a synonym for cuts in social services. Low salary and missing protection laws are so-called advantages of a business location and a sign of so-called attractive business locations. The consequence is a legal protection racket - the start of a race for the most antisocial life and work conditions (Podszuweit, 1996: 188). The barbed slogans of neo-liberal ideology are designed to undermine relations of social solidarity and to transform solidarity into a profit-based dependence on those above and ruthlessness vis-à-vis those below

\section{8 articles}


(Gerlach, 2000). Social manifestations considered as negative are no longer denied, but rather regarded as socially unavoidable conditions, the so-called material constraints. Mrs. Thatcher's bon mot »There is no alternative " underlines this alleged inevitability. Political dealings, which are driven by specific interests, are thus passed off as the unavoidable operation of anonymous forces pointing in the direction of the only possible and sensible way out (Forrester, 1997: 16). Neo-liberal myths and dogmas join up with these neo-liberal toxic notions. Neoliberalism emerges as a type of new world religion with a claim to absolute validity, which is otherwise associated with various forms of religious fundamentalism. These dogmas and myths are reflected in slogans such as: "We can no longer afford the welfare state", »/f the economy works well, everybody is better off « or »Economic growth produces jobs«. All of these toxic ideas and myths are chanted like mantras by politicians, economic experts and representatives of the media. This explains why these septic concepts are so deeply anchored in the consciousness of the population, although their empirical experience of what is actually happening and numerous studies contradict them (WIFO-Weißbuch, 2006; Reimon and Felber, 2003). The question concerning the ability to finance the welfare state is not a question of inadequate resources but of political will and distribution. The current gulf between rich and poor, - not only within the state but also between states - contradicts the dogma that a flourishing economy is a blessing for all and that growth brings jobs. If companies make a profit, their share price rises, which means that not everybody is better off - only the board of directors, the managers and the shareholders. Despite this, workers are laid off. If the welfare and woe of an economy depended on low wages or the additional costs of pension and social insurance payments, as the neo-liberals argue, then countries such as Bangladesh or Somalia would have had full employment long ago and be living in luxury.

\section{CONSEQUENCES AND CHALLENGES FOR SOCIAL WORK}

\section{The Demolition and transformation of the welfare state. Workfare instead of welfare}

One consequence of neo-liberal politics is the demolition of the welfare state. As a consequence, new social problems and focal points have emerged and with them more tasks for social work, yet resources have been either frozen or cut (Albert, 2006). The dynamic workfare state has superseded the active welfare state. By means of neo-liberal neologisms such as "promote and demand", »help only for the really needy", »an end to the state benefit mentality", unemployment and poverty, according to the Social Darwinist canon, have become problems of 
the individual, of character weakness and a lack of readiness to perform in a job. In an economy where jobs, but not those willing to work are missing, the pressure to find paid work is increased without any attempt to improve the chances of the socially disadvantaged (Kessl, 2006: 34). Activation, in a broader context, amounts to nothing more than a kind of authoritarian withdrawal of social rights: Help to find work is transformed into threats of forced labor. Hence, the welfare state becomes a goal-oriented workfare state resorting to oppression and social exclusion (Dimmel, 2006). Citizens with inalienable rights have become economic citizens who have rights only over what they can buy. The community becomes divided into a welfare state market on the one hand and into a charity state on the other. Those citizens who can afford it buy social security (i.e. care for the aged). At the same time, the workfare state offers only a minimum of protection for people's existential needs, otherwise they are handed over to private charitable organizations (Jones, 2001).

\section{Economization of social work}

The economization of social work means that social work has been subjected to the logic of the market and its profit orientation. This is connected to implementing methods and concepts of business administration and private entrepreneurship and running social work much like a private company. This idea has found popularity with its promises of more effectiveness and efficiency and is linked to a visible, improvement of quality in social work (Albert, 2006: 26-31; Dahme and Wohlfahrt, 2006: 61). Social work clients have mutated into customers and as such they are themselves responsible for the causes of their difficulties, but above all, for finding a solution to their problems. Yet, the term customer is a euphemism and inappropriate in the context of social work clients. Customers can choose between different services and have financial resources to buy the products. Clients of social work are people in need who cannot help themselves, they have psycho-social problems but not because they chose them like a product in the supermarket. The economy wants customer retention: more customers mean more profit. Social Work tries to make itself redundant, to help the clients help themselves with strategies of empowerment. Ultimately, the goal is to get rid of them (Cowden and Singh, 2007; Spolander et al., 2014: 306; Staub-Bernasconi, 2007).

\section{Competition instead of solidarity}

Social associations and institutions have been transformed into companies based on managerial thinking, using performance-related contracts and invitations

\section{0 articles}


to competitive tender (Flösser and Vollhase, 2006: 81; Ebert, 2013: 15). The central, provincial or local governments, who pay the bills, hence have expectations that increased competition will improve the efficiency of the staff and the effectiveness of the service provided which, above all, will result in lowered costs. But the philosophy of cost efficiency and competition has a destructive effect. It inspires the social services to drop the quality standards to get the biggest piece of the budget-cake. Also creaming-effects are on the rise in the support system of fringe groups: specifically, there is a tendency towards the displacement of the weakest clients in favor of clients who are more easily looked after with positive results. Only those clients are advised who did not cause their predicament through gross negligence and who can be settled with little cost to the financial backer. In addition, the marketing of the social product is becoming more important than de-stigmatizing lobbying and public relations for the clientele (Matt, 2005: 360; Diebäcker et al., 2009)

\section{Economy before professionalism}

In the analysis of the economic processes of social work since the 1990s, too little attention has been paid to the fact that the point of departure is not the wellbeing of the client and an improvement in the quality of the social work, but more the pressure to save resources. Success in saving costs seems to be more important than success in support. The influence of neoliberalism on social work includes the deskilling of social work through McDonaldization (Ritzer, 2011) by which quantity is often ranged with quality (Spolander, Engelbrecht and Pullen, 2015: 9). The economization of social work is a kind of Trojan horse. Professional social work is used to follow aims inimical to the profession: as a rule, making successful savings is placed above success in providing help. Strict housekeeping, costing - but not the professional client-centered diagnosis are the factors that determine whether an approach is useful, efficient and feasible; social work is being driven by the logic of business administration, expressed in competitive contracts, the formalization of advisory and supervisory services as a product, standardized production and provision of these services (Ferguson, Lavalette and Whitmore, 2004; Harris and White, 2009). Instead of building a relationship with the client, it is all about the most efficient management of the case possible. There are also changes in the role of social work: social workers function more like deputy sheriffs than advocates for clientele. They are e.g. misused or let themselves be misused to do the job of security services in a more psychological and non-violent way to keep marginalized groups off the streets in city centers, railway stations and shopping malls to make these areas more customer-friendly (Schnurr, 2005: 239-240; Schönig, 2006: 28). Social workers also have to face up to the old accusation of being nurses of capitalism; of 
only being a repair company for the amelioration of negative social and economic consequences, conserving poverty instead of enhancing real inclusion and effecting social change (Holstein and Meinhold, 1973).

\section{THE REACTION OF SOCIAL WORK}

The reaction of social work to the economization of the social sphere is varied: uncritical adoption (Jordan, 2005; Asquith, Clark and Waterhouse, 2005; Jones and Truell, 2012), ambivalence (Meinhold, 1998; Gaitanides, 2000; Kleve, 2003) and resistance (Ife, 2001; Staub-Bernasconi, 2007; Dominelli, 2009; Ferguson and Woodward, 2009; Garrett, 2009; Seithe 2010; Spolander et al., 2014; Turbett, 2014).

Seithe designs a typology of reacting and distinguishes the following types: patient helpers, who are doing extra work in their leisure time or accept unpaid extra hours; the conservatives, who flee into niches and dream of old times; the clever tricksters, who try to compensate the cut in funding by getting money some other way e.g. by project-funding or donations; the unperturbed professionals, who see a challenge in economization for professional development and try to describe their job in economic terms; the harmonizers, who downplay the differences and the contradictions between social work and economization ideology, the realists, who have a critical attitude but see development of economization as inevitable; the modernizers, who affirm such economization as a chance for professionalization and the winners of modernization, who are explicit advocates of the economization of social work (Seithe, 2010: 233-243).

Lorenz $(2005 a, 2005 b)$ states that social work has proved adaptable and uncritical of its own role in neoliberal changes. Social workers withdraw to privatization, psycho-therapeutic approaches or accept models of New Public Management without opposition. Jones and Truell (2012) describe social work as a profession which is often uncritical, influenced by low morale and is not fulfilling its political mandate. Social work has resulted in a profession which is unconsciously or consciously aiding neoliberal reforms (Jones and Truell, 2012). Social work and especially managers of social work services, largely untested, adopt business concepts and apparatus applied to social work. Neo-liberal dogma is repeated in parrot fashion and the efficiency and effectiveness of the neo-liberal economy are presented relatively uncritically without reflecting on where efficiency and effectiveness really stand in the equation. The public and private sponsors of social service departments bring in consultants who have no operative knowledge of social work but who believe they are qualified to evaluate whether jobs should be cut or not (Galuske, 2008:19).

Dimmel (2006) describes these cases as an assimilation position. Kleve (2003: 14) observes an ambivalent relationship between social work and economization:

\section{2 articles}


"The neo-liberal transformation of the welfare state community cannot, from the perspective of the social worker, be explicitly condemned nor greeted with pleasure". Wolf and other authors state that the struggle for more efficiency must not harm the quality of social work (Kreuzer, 2001; Galuske, 2002; Wolf, 2006: 294). Brülle and Altschiller (1992: 58) suggest adopting those parts of neoliberal economy which make sense in the context of social work, but argue that concepts of management must not superpose the professional contents of social work. Dimmel (2006) refers to a position of adaptation, which does not criticize the economization of social work in the sense of its effectiveness, but the neo-liberal understanding of it.

A final reaction is the renewal of the socially-critical political function of social work (Lindenberg, 2000; Kruse, 2004; Haupert, 2005; Powell and Gheoghegan, 2005; Ferguson and Lavalette, 2006; Rogowski, 2013; Spolander, Engelbrecht and Pullen, 2015). There is different wording concerning social work, which fulfils its political mandate as formulated in the Code of Ethics of the International Federation of Social Workers - IFSW (IFSW, 2004): radical social work (Brake and Bailey, 1980; Ferguson and Woodward, 2009; Lavalette, 2011; Turbett, 2014), critical social work (Allan, Briskman and Pease, 2009; Campbell and Baikie, 2012; Stepney, 2006), structural social work (Mullaly, 2007) or political social work (Stark, 2007; Shannon and Pritzker, 2018). This kind of social work has a long tradition and reconsiders the prior criticism that social workers serve as »nurses of capitalism « (Holstein and Meinhold, 1973: 205) and »make the hell more palatable to the clients« (Alinski, 1974, cited in Kunstreich, 2001:134). Bourdieu (1998) offers the view that in this context social work is a refutation of the neo-liberal invasion oriented towards social justice.

Ferguson (2004) argues: „Yet in many respects the need for a radical, empowering social work is greater than ever«. Spolander, Engelbrecht and Pullen (2015: 11) state that "... key challenges for practitioners are the ongoing development and consolidation of their understanding of the systemic linkages between critical policy analyses, the complexity of the policy-practice nexus and management ... This inevitably means being more vocal into policy debates, contributing to macro and micro welfare policy and practice development, and helping communities to understand the implications of social inequality. This will inevitably mean the need for the profession to develop policy specialists and forging greater links with citizens and civil movements.".

Thus, social work is not simply at the mercy of the hierarchy of power and resistance to policy which requires adaption to the force of circumstance being possible. Political social workers are considered as social workers who do not serve as objects of the existing power relations but try - as empowered subjects - to influence structures which cause the social problems of their clients and so co-design social policy (Stark, 2007: 70). 


\section{CONCLUSIONS}

Peter Drucker, one of the most esteemed economists of the 20th century, defines effectiveness and efficiency as follows: »Efficiency is doing things right; effectiveness is doing the right things (van Vliet, 2010). Drawing on this definition, I would like to ask the proponents of the neo-liberal economy the following: how effective and efficient is the world economy dominated by neo-liberal ideology when 18,000 children starve every day, while at the same time food surpluses are destroyed? (FAO, 2005: 6-7). How effective and efficient is an economy which sees the production and export of huge amounts of food from Third World countries as feed for European livestock while the local population vegetates under the subsistence level and, to some extent, even starves? How effective is a global economy which is destroying the environment and ruthlessly exploits labor in the interest of profit maximization and which is also responsible for 186 million children working under conditions not far from slavery to enlarge the profits of multinational companies? (ILO, 2002).

Is it really necessary for social work to adopt these neo-liberal standards and lower itself to the level of economic efficiency and effectiveness, which is contemptuous of mankind? It goes without saying that social work should always pose the question of whether it is doing the right things correctly and to reflect and evaluate them in a scientific and professional manner. But not under the overall control of managers and business management fetishists for whom efficiency means profit-maximization and effectiveness is only doing the job as economically as possible.

Whether someone gets the necessary means for a life worth living cannot be decided by the market. Social work is not a commodity, but the result of the common efforts of all participants and the simultaneous management of circumstances, which makes success more likely (Galuske 2002: 328).

Social Work is a service which needs standards but these standards must be established by social work professionals and not by economists and managers. Social Work performance cannot be standardized like merchandise. Clients are human beings and not standardizable industrial products (Thole and Cloos, 2000; Galuske and Müller 2002: 488; Staub-Bernasconi, 2007: 36). You cannot predict the reaction of clients - therefore, the success of social work does not only depend on a social worker's performance, but on the motivation and actions of the clients, as well as on circumstances social workers cannot influence directly such as laws, the labor and the housing market, etc. Any given counseling session with a client may take 10 minutes or an hour - the decision of how much time needs to be invested must be up to the professional social worker. Economization and standardization of social work means the death of autonomous and professional social work (Strunk, 1997: 184; Manderscheid, 1998; Butterwege, 1999).

\section{4 articles}


Hence, social work as an integral part of social policy must be understood as more than a repair company for the appeasement of negative social and economic consequences. Social Work is not simply at the mercy of the hierarchy of power. Resistance to policy, which requires adaption to the force of circumstance, is possible. This means that social work - by analyzing social problems - should turn its main attention to socially determined structural causes, should make them public, interfere in current socio-political debates, and thereby create a counter-opinion in public discourse.

The resistance is based on a well-founded scientific analysis of the problems of the clients of social work and their social structural reasons and a code of ethics which questions the neoliberal world religion on the background of human rights and the principals of social justice.

The International Federation of Social Work has also defined this as a central task in the professional operation of social work: "Social workers have a duty to bring to the attention of their employers, policy makers, politicians and the general public situations where resources are inadequate or where distribution of resources, policies and practices are oppressive, unfair or harmful.« (IFSW, 2012).

REFERENCES

1. Allan, J., Briskman, L. \& Pease, B. (2009). Critical social work. Theories and practices for a socially just world. London: A\&U Academic.

2. Albert, M. (2006). Die Ökonomisierung der Sozialen Arbeit. Neue Hierarchien innerhalb der Profession [The economization of social work. New hierarchies within the profession]. Sozial Extra, 30 (7-8), 26-31.

3. Altvater, E. (1981). Der gar nicht diskrete Charme der neoliberalen Konterrevolution [The non discreet charm of the neoliberal counterrevolution]. Prokla, 44 (3), 5-23.

4. Asquith, S., Clark, C. \& Waterhouse, L. (2005). The role of the social worker in the 21st century-a literature review. Retrieved from: http://www.gov.scot/Resource/ Doc/47121/0020821.pdf. (2.11.2009).

5. Blankenburg, S. (1997). Der Neoliberalismus als theoretisches Konzept und Wegbereiter des modernen Rechtsextremismus. Freier Markt und Meinungsführerschaft [Neoliberalism as an theoretical concept and forerunner of modern right-wing extremism. Free market and opinion leadership]. In: Schui, H., Ptak, R. \& Blankenburg, S. (eds.), Wollt ihr den totalen Markt? Der Neoliberalismus und die extreme Rechte [Do you want the total market? Neoliberalism and the extreme rights]. München: Knaur, $53-111$.

6. Bourdieu, P. (1998). Der Mythos "Globalisierung" und der europäische Sozialstaat [The myth of globalisation and theE European welfare state]. In: Bourdieu, P. 
(ed.), Gegenfeuer. Wortmeldungen im Dienste des Widerstands gegen die neoliberale Invasion [Backfire. Comments in the service of resistance against the neoliberal invasion]. Konstanz: Univ. Verlag Konstanz, 39-52.

7. Brake, M. \& Bailey, R. (1980). Radical social work and practice. London: Hodder \& Stoughton Educational.

8. Brülle, H. \& Altschiller, C. (1992). Sozialmanagement. Dienstleistungsproduktion in der kommunalen Sozialverwaltung [Social management. Service production in the local self-government]. In: Flösser, G. \& Otto, H-U. (eds), Sozialmanagement oder Management des Sozialen [Social management or management of "the social issue $]$. Bielefeld: Böllert, 145-165.

9. Butterwegge, C. (1999). Herrschaft des Marktes - Abschied vom Staat [Reign of the market - Resignation of the state]. Baden: Nomos.

10. Butterwege, C., Lösch, B. \& Ptak, R. (2008). Kritik des Neoliberalismus [Critique of neoliberalism]. Wiesbaden: Springer.

11. Campbell, C. \& Baikie, G. (2012). Beginning at the beginning: An exploration of critical social work. Critical Social Work, 13 (1), 67-81.

12. Chomsky, N. \& Achbar, M. (1996). Wege zur intellektuellen Selbstverteidigung. Medien, Demokratie und die Fabrikation von Konsens [Strategies for intellectual selfdefense. Media, democracy and fabrication of consent]. München: Marino.

13. Chomsky, N. (1997). On power, knowledge and human nature. London: Palgrave.

14. Chomsky, N. (2010). Hopes and prospects. Retrieved from: https://speakingofdemocracy.com/2010/07/chomsky-hopes-and-prospects (20.6.2017).

15. Cowden, S. \& Singh, G. (2007). The »user«: Friend, foe or fetish? A critical exploration of user involvement in health and social care. Critical Social Policy, 27, 5-23.

16. Dahme, H. J. \& Wohlfahrt, N. (2006). Strömungen und Risiken der Verwaltungsmodernisierung in der Jugendhilfe [Trends and risks of administrative modernization in youth welfare]. In: Hensen, G. (ed.), Ökonomisierung im Kontext von Zukunftorientierung und fachlicher Notwendigkeit [Economisation in the context of future orientation and professional necessity]. Weinheim: Juventa, 61-76.

17. Diebäcker, M., Ranftler, J., Strahner, T. \& Wolfgruber, G. (2009). Zeugnisse alltäglichen Leidens in sozialen Organisationen. Von der Ökonomisierung des Politischen zur Depolitisierung und Deprofessionalisierung der Sozialen Arbeit [Testimonies of daily suffering in social organisations. From economisation of political issues to de-politication and de-professionalisation of social work]. Soziales_kapital, 4, 1-16.

18. Dimmel, N. (2006). Verbetriebswirtschaftlichung, Privatisierung und sozialarbeiterisches (Doppel)Mandat - ein Bermuda-Dreieck der sozialen Arbeit? [ Economisation, privatisation and the double mandate of social work-a Bermuda triangle of social work]. Retrieved from: www.sozialearbeit.at. (17.8.2017).

\section{6 articles}


19. Dominelli, L. (2009). Repositioning social work. In: Adams, R., Dominelli, L. \& M. Payne (eds.), Social work: Themes, issues and critical debates ( $2^{\text {nd }}$ edition). Basingstoke: Palgrave Macmillan, 13-25.

20. Ebert, J. (2013). New Managerialism. Eine Gefahr für die Profession? - Die Bedeutung der Aufhebung demokratischer Strukturen für die Arbeitsbeziehungen in der Sozialen Arbeit [New Managerialism. A danger for social work profession? The meaning of cancellation of democratic structures for labour relations in social work]. Retrieved from: http://www.hawkhhg.de/sozialearbeitundgesundheit/media/ Soziale_Arbeit_und_Demokratie.pdf. (6.3.2018).

21. FAO - Food and Agriculture Organisation (2005). The state of food insecurity in the world. Rome: FAO.

22. Ferguson, I. (2004). Neoliberalism, the third way and social work: The UK experience. SW\&S -Social work and Society. International Online Journal, 2 (1), 1-9.

23. Ferguson, I. \& Woodward, R. (2009). Radical social work in practice. Making a difference. Bristol: The Policy Press.

24. Ferguson, I., Lavalette, M. \& Whitmore, E. (2004). Globalisation, global justice and social work. London: Routledge.

25. Ferguson, I. \& Lavalette, M. (2006). Globalisation and global justice: Towards a social work of resistance. International Social Work, 49 (3), 309-318. https://doi. org/10.1177/0020872806063401

26. Flösser, G. \& Vollhase, M. (2006). Freie Wohlfahrtspflege zwischen subsidiärer Leistungserbringng und Wettbewerb [Independent welfare between subsidiary service provision and competition]. In: Hensen, G. (ed.), Ökonomisierung im Kontext von Zukunftsorientierung und fachlicher Notwendigkeit [Economisation in the context of future orientation and professional necessity]. Weinheim: Juventa, 77-88.

27. Forrester, V. (1997). Der Terror der Ökonomie [The economy's reign of terror]. Wien: Zsolnay.

28. Friedman, M. (1976). Kapitalismus und Freiheit [Capitalism and Freedom]. Stuttgart: Deutscher Taschenbuch Verlag.

29. Gaitanides, S. (2000). Soziale Arbeit - im Spagat zwischen Ökonomisierung und Menschenrechtsprofession [Social work between the poles of economisation and human rights profession]. In: Elsen, S., Lange, D. \& Wallmann, I. (eds.), Soziale Arbeit und Ökonomie: Politische Ökonomie - Arbeitsmärkte - Sozialpolitik Grenzen der Ökonomisierung - Soziale Ökonomie Gemeinwesenentwicklung - Bürgergesellschaft [Social work and economy: political economy - labour markets-social policy. Limits of economisation - social economy community organizing - civil society]. Neuwied: Luchterhand, 125-136.

30. Garrett, P. M. (2009). Marx and modernization: Reading capital as social critique and inspiration for social work resistance to neoliberalization. Journal of Social Work, 9, 199-221. https://doi.org/10.1177/1468017308101822 
31. Galuske, M. (2002). Flexible Sozialpolitik. Elemente einer Theorie Sozialer Arbeit in der modernen Arbeitsgesellschaft [Flexible social policy. Elements of a theory of social work in modern work society]. Weinheim: Beltz-Juventa.

32. Galuske, M. \& Müller, W. C. (2002). Handlungsformen in der Sozialen Arbeit. Geschichte und Entwickung. In: Thole, W. (ed.), Grundriss Soziale Arbeit [Outline social work]. Opladen: Verlag für Sozialwissenschaften, 485-508.

33. Galuske, M. (2008). Fürsorgliche Aktivierung. Anmerkungen zu Gegenwart und Zukunft Sozialer Arbeit im aktivierenden Staat [Caring activation. Comments to present and future of social work in the context of the activating welfare state]. In: Bülow, B. et al. (eds.), Soziale Arbeit nach dem sozialpädagogischen Jahrhundert [Social work after the social pedagogic century]. Opladen: Budrich, 9-28.

34. Gerlach, T. (2000). Denkgifte. Psychologischer Gehalt neoliberaler Wirtschaftstheorie und gesellschaftspolitischer Diskurse [Poisoning of thought. The psychological content of neoliberal economic theory and sociopolitical discourses]. Bremen: Universität Bremen.

35. Gray, J. (1999). Die falsche Verheißung. Der globale Kapitalismus und seine Folgen, Berlin [The false promise. Global capitalism and its consequences]. Retrieved from: http://www.uunpb.org/John-Gray.pdf (6.7.2017).

36. Green, D. (1995). Silent Revolution. The Rise of Markets and Economics in Latin America. Guilford: NYU Press.

37. Harris, J. \& White, V. (2009). Modernising social work: Critical considerations. Bristol: Policy Press.

38. Harvey, D. (2007). Kleine Geschichte des Neoliberalismus [A short history of neoliberalism]. Zürich/New York: Rotpunkt.

39. Haupert, B. (2005). Gegenrede: Wider die neoliberale Invasion der Sozialen Arbeit [Counter declaration. Against the neoliberal invasion of social work]. Retrieved from: http://www.qualitative-sozialforschung.de/haupert.htm (7.6.2017).

40. Hayek, F. A. (1954). Marktwirtschaft und Wirtschaftspolitik [Market economy and economic politics]. ORDO, 6, 3-17.

41. Hayek, F. A. (1971). Die Verfassung der Freiheit [The constitution of liberty]. Tübingen: Mohr.

42. Hayek, F. A. (1979). Liberalismus. Vorträge und Aufsätze [Liberalism. Lectures and essays]. Tübingen: Mohr.

43. Hennecke, H. J. (2000). Friedrich August von Hayek. Die Tradition der Freiheit [Friedrich August von Hayek. The tradition of liberty]. Düsseldorf: VS Verlag für Sozialwissenschaften.

44. Herman, E. S. \& Chomsky, N. (1994). Manufacturing consent: The political economy of the mass media. London: Vintage books.

\section{8 articles}


45. Hollstein, W. \& Meinhold, M. (1973). Sozialarbeit unter kapitalistischen Produktionsbedingungen [Social work under capitalistic production conditions]. Frankfurt a. Main: Fischer.

46. Ife, J. (2001). Local and global practice: Relocating social work as a human rights profession in the new global order. European Journal of Social Work, 4 (1), 5-15. https://doi.org/10.1080/714052835

47. ILO-International Labour Organisation (2002). Jedes Kind zählt [Every child counts]. Genf: ILO.

48. International Federation of Social Work - IFSW (2012). Code of Ethics. Retrieved from: http://ifsw.org/policies/statement-of-ethical-principles (2.10.2017).

49. Jäger, S. (1994). Text und Diskursanalyse. Eine Anleitung zur Analyse politischer Texte [Text and discourse analysis. An instruction to analyse political texts]. Duisburg: DISS-Texte.

50. Jones, C. (2001). Voices from the front-line. State social workers and new labour. British Journal of Social Work, 31 (4), 547-562. https://doi.org/10.1093/ bjsw/31.4.547

51. Jones, D. \& Truell, R. (2012). The global agenda for social work and social development: A place to link together and be effective in a globalized world. International Social Work, 55 (4), 454-72. https://doi.org/10.1177/0020872812440587

52. Jordan, B. (2005). New labour: Choice and values. Critical Social Policy, 25, 427-446.

53. Kessl, F. (2006). Sozialer Raum als Fall? [Social space as a case]?. In: Galuske, M. \& Thole, W. (eds.), Vom Fall zum Management. Neue Methoden in der Sozialen Arbeit [From case to management. New methods in social work]. Wiesbaden: Verlag für Sozialwissenschaften, 37-54.

54. Kleve, H. (2003). Sozialarbeitswissenschaft, Systemtheorie und Postmoderne [Social work science, systems theory and post modernism]. Freiburg i.B.: VS Verlag für Sozialwissenschaften.

55. Krätke, M. (1999). Neoklassik als Weltreligion [Neo-classics as world religion. Critical interventions]. Kritische Interventionen, 3, 100-144.

56. Kreuzer, F. (1983). Markt, Plan, Freiheit. Franz Kreuzer im Gespräch mit Friedrich A. Hayek u. Ralf Dahrendorf [Market, plan, liberty. Franz Kreuzer in dialogue with Friedrich A. Hayek and Ralf Dahrendorf]. Wien: Deuticke.

57. Kreuzer, M. (2001). Handlungsmodelle in der Familienhilfe. Zwischen Networking und Beziehungsempowerment [Action models in family assistance. Between the poles of networking and empowerment of relations]. Neuwied: Luhterhand.

58. Kruse, J. (2004). Soziale Arbeit als disziplinierende Simulation. Eine kritische Analyse der Ökonomisierung Sozialer Arbeit [Social work as a disciplining simulation. A critical analysis of the economization of social work]. Soziale Arbeit, 7, 256-262. 
59. Kunstreich, T. (2001). Grundkurs Soziale Arbeit. Sieben Blicke auf Geschichte und Gegenwart Sozialer Arbeit [Basic Course in social work. Seven glances at the history and present of social work]. Bielefeld: USP International.

60. Kurz, R. (2001). Schwarzbuch Kapitalismus. Ein Abgesang auf die Marktwirtschaft [Black book capitalism. A swan song for the market economy]. München: Eichhorn.

61. Lavalette, M. (2011). Radical social work today: Social work at the crossroads. Bristol: Policy Press.

62. Lindenberg, M. (2000). Von der Sorge zur Härte. Kritische Beiträge zur Ökonomisierung Sozialer Arbeit [From care to hardness. Critical contributions to the economisation of social work]. Bielefeld: Kleine.

63. Lorenz, W. (2005a). Social work and a new social order: Challenging new liberalism's erosion of solidarity. Social Work and Society, 3, 93-101.

64. Lorenz, W. (2005b). Social work and the Bologna process. Social Work and Society, $3,224-235$.

65. Maaser, W. (2003). Normative Diskurse der neuen Wohlfahrtspolitik [normativ discourses of the new welfare policy]. In: Dahme, H. J. et al. (eds.), Soziale Arbeit für den aktivierenden Sozialstaat [Social work for the activating welfare state]. Opladen: Leske Budrich, 217-232.

66. Manderscheid, H. (1998). Solidarität stiften statt Fürsorge organisieren [Creating solidarity instead of organising care]. Blätter der Wohlfahrtspflege, 11, 238-241.

67. Martin, H. P. \& Schumann, H. (1996). Die Globalisierungsfalle. AngriffaufDemokratie und Wohlstand [The globalisation trap. Attack on democracy and wealth]. Reinbeck: Rowohlt.

68. Matt, E. (2005). Ausbildung und Berufsqualifikation [Education and professional qualification]. In: Anhorn, R. \& Bettinger, F. (eds.), Sozialer Ausschluss und Soziale Arbeit. Positionsbestimmungen einer kritischen Theorie und Praxis Sozialer Arbeit [Social exclusion and social work. Position determination of a critical theory an practice of social work]. Wiesbaden: Verlag für Sozialwissenschaften, 351-365.

69. Meinhold, M. (1998). Qualitätssicherung und Qualitätsmanagement in der Sozialen Arbeit [Quality assurance and quality management in social work]. Freiburg i. Breisgau: Lambertus.

70. Mullaly, B. (2007). The new structural social work (3rd edition). Toronto: Oxford University Press.

71. Nawroth, E. (1961). Die Sozial- und Wirtschaftsphilosophie des Neoliberalismus [Social and economic philosophy of neoliberalism]. Heidelberg: Kerle.

72. Negt, O. (1997). Neuzugänge zum Marx'schen Denken [New approaches to marxist theory]. Z.: Zeitschrift Marxistische Erneuerung, 30, 38 - 46.

73. Orwell, G. (2008). 1984. Retrieved from: http://gutenberg.net.au/ebooks01 /0100021.txt (4.6.2017).

\section{0 articles}


74. Polanyi, K. (1978). The great transformation. Frankfurt: Suhrkamp.

75. Podszuweit, H. J. (1996). Zur Logik der Standortpolitik [The logic of location policy]. Z. Zeitschrift Marxistische Erneuerung, 25, 188-189.

76. Powell, F. \& Geoghegan, M. (2005). Community development, partnership governance and dilemmas of professionalization: Profiling and assessing the case of Ireland. The British Journal of Social Work, 36 (5), 845-861. https://doi. org/10.1093/bjsw/bch344

77. Reimon, M. \& Felber, C. (2003). Schwarzbuch Privatisierung [Black book privatisation]. Wien: Vienna/Wien Publisher: Wirtschaftsverlag Ueberreuther.

78. Ritzer, G. (2011). The McDonaldization of society (6th edition). Thousand Oaks, CA: Pine Forge Press.

79. Rogowski, S. (2013). Neoliberalism and social work: Facing the challenges. Retrieved from: http://www.policypress.co.uk (28.2.2018).

80. Schnurr, S. (2005). Managerielle Deprofessionalisierung? [Deprofessionalisation by management?]. Neue Praxis, 35 (3), 239-242.

81. Schönig, W. (2006). Aktivierungspolitik [Activation policy]. In:Dollinger, B. \& Raithel, J. (eds), Aktivierende Sozialpädagogik. Ein kritisches Glossar [Activating social pedagogics. A critical glossary]. Wiesbaden: Verlag für Sozialwissenschaften, 23-40.

82. Rosen, R. (1981). Geschichte der politischen Ideen. Von Homer bis zur Gegenwart [A history of political ideas. From homer up to the present]. Königstein: Athenaeum.

83. Shannon, R. \& Pritzker, L. (2018). Political social work: Using power to create social change. Cham: Springer.

84. Seithe, M. (2010). Schwarzbuch Soziale Arbeit [Black book of social work]. Wiesbaden: VS Verlag für Sozialwissenschaften.

85. Smith, A. (1976). An inquiry into the nature and causes of the wealth of nations. Chicago: University of Chicago Press.

86. Spolander, G., Engelbrecht, L., Martin, L., Strydom, M., Pervova, I., Marjanen, P., Tani, P., Sicora, A.\& Adaikalam, F. (2014). The implications of neoliberalism for social work: Reflections from a six-country international research collaboration. International Social Work, 57 (4), 301-312. https://doi.org/10.1177/0020872814524964

87. Spolander, G., Engelbrecht, L. \& Pullen-Sansfacon, A. (2015). Social work and macro-economic neoliberalism: Beyond the social justice rhetoric. European Journal of Social Work, 1-16, doi:10.1080/13691457.2015.1066761

88. Stark, C. (2007). Politisches Engagement in der Sozialarbeit [Political engagement in social work.]. In: Lallinger, M. \& Rieger, G. (eds.), Repolitisierung Sozialer Arbeit [Re-politication of social work]. Stuttgart: Verlag Akademie der Diözese Rottenburg, 69-84.

89. Staub-Bernasconi, S. (2007). Soziale Arbeit: Dienstleistung oder Menschenrechtsprofession? Zum Selbstverständnis Sozialer Arbeit in Deutschland mit einem 
Seitenblick auf die internationale Diskussionslandschaft [Social work: service or human rights profession? Self-conception of social work in Germany with a side on the international discourse]. In: Lob-Hüdepohl, A. \& Lesch, W. (eds.), Ethik Sozialer Arbeit - Ein Handbuch: Einführung in die Ethik der Sozialen Arbeit [Ethics of social work - a manual: introduction to ethics of social work]. Paderborn, München, Wien \& Zürich: UTB, 20-54.

90. Stepney, P. (2006). Mission impossible. Critical practice in social work. British Journal of social work, 36 (8), 1289-1307. https://doi.org/10.1093/bjsw/bch388

91. Stern, N. (2002). IWF und Weltbank appellieren: Subventionen und Zölle auf Agrarprodukte aus Entwicklungsländern sollen abgebaut warden. Retrieved from: http:// derstandard.at/1084641/Oeffnet-die-Maerkte. (2.7.2017).

92. Strunk, A. (1997). Von der fehlerlosen zur fehlerbewussten Organisation [From error free organisation to error recognizing organisation]. Blätter der Wohlfahrtspflege, 9 (97), 184-187.

93. Thole, W. \& Cloos, P. (2000). Soziale Arbeit als professionelle Dienstleistung. Zur Transformation des beruflichen Handelns zwischen Ökonomie und eigenständiger Fachkultur [Social work as a professional service. Transformation of professional action between economy and independent professional culture]. In: Müller, S., Sünker, H. \& Olk, T. (eds.), Soziale Arbeit zwischen Politik und Dienstleistung [Social work between politics and service]. Neuwied: Böllert, 535-556.

94. Turbett, C. (2014). Doing radical social work. New York: St. Martin's Press LLC.

95. van Vilet, V. (2010). Peter Drucker. Retrieved from: https://www.toolshero.com/ toolsheroes/peter-drucker (22.6.2017).

96. WIFO-Weißbuch (2006). MehrBeschäftigung durch Wachstum aufBasis von Innovation und Qualifikation [More employment by growth on the base of innovation and qualification]. Retrieved from: http://test.wifo.ac.at/wwa/servlet/wwa.upload. DownloadServlet/bdoc/S_2006_WEISSBUCH_ZUSAMMENFASSUNG_27639\$. PDF (2.8.2017).

97. Wilke, G. (2002). John Maynard Keynes. Frankfurt a. Main: Campus.

98. Wolf, K. (2006). Wie wirken pädagogische Interventionen? [What are the effects of pedagogic interventions?]. Jugendhilfe, 44 (6), 294-301.

\section{2 articles}


Christian Stark

Sveučilište primijenjenih znanosti Gornje Austrije

\section{NEOLIBERALNA IDEOLOGIJA, NJEZINE PROTURJEČNOSTI, POSLJEDICE I IZAZOVI ZA SOCIJALNI RAD}

\section{SAŽETAK}

U članku je prikazan utjecaj neoliberalizma na socijalni rad te su predloženi odgovori u skladu s Etičkim kodeksom Međunarodne federacije socijalnog rada (4.2.4. Socijalna pravda - Suprotstavljanje nepravednim politikama i praksama). Neoliberalizam se može opisati kao gospodarsko-politički projekt kapitalističkih elita koji uključuje: ekonomizaciju svih područja života, privatizaciju, ekonomsku globalizaciju i deregulaciju. U članku se iznosi kratak povijesni pregled razvoja neoliberalizma, mitova i načela neoliberalne ideologije te »proizvodnje pristanka« (Herman i Chomsky, 1994.). Osim toga, opisuju se posljedice za socijalnu politiku i socijalni rad koje uključuju smanjenje socijalne države i razvoj koji se može opisati sljedećim ključnim pojmovima: ekonomizacija socijalnog rada, pomoć temeljena na radu (engl. workfare) umjesto socijalne skrbi (engl. welfare). Konačno, u članku se navode reakcije socijalnog rada na takav razvoj. Također se raspravlja i o nekim nužnim strategijama za pozitivno djelovanje.

Ključne riječi: Neoliberalizam, radikalni/kritički socijalni rad, ekonomizacija socijalnog rada, socijalna politika.

Međunarodna licenca / International License:

Creative Commons Attribution-NonCommercial-NoDerivatives 4.0. 
